IZA DP No. 5954

Women's Age at First Marriage and Marital Instability: Evidence from the 2006-2008 National Survey of Family Growth

Evelyn L. Lehrer Yu Chen

September 2011 


\title{
Women's Age at First Marriage and Marital Instability: Evidence from the 2006-2008 National Survey of Family Growth
}

\author{
Evelyn L. Lehrer \\ University of Illinois at Chicago \\ and IZA \\ Yu Chen \\ University of Illinois at Chicago
}
Discussion Paper No. 5954
September 2011

\author{
IZA \\ P.O. Box 7240 \\ 53072 Bonn \\ Germany \\ Phone: +49-228-3894-0 \\ Fax: +49-228-3894-180 \\ E-mail: iza@iza.org
}

\begin{abstract}
Any opinions expressed here are those of the author(s) and not those of IZA. Research published in this series may include views on policy, but the institute itself takes no institutional policy positions.

The Institute for the Study of Labor (IZA) in Bonn is a local and virtual international research center and a place of communication between science, politics and business. IZA is an independent nonprofit organization supported by Deutsche Post Foundation. The center is associated with the University of Bonn and offers a stimulating research environment through its international network, workshops and conferences, data service, project support, research visits and doctoral program. IZA engages in (i) original and internationally competitive research in all fields of labor economics, (ii) development of policy concepts, and (iii) dissemination of research results and concepts to the interested public.
\end{abstract}

IZA Discussion Papers often represent preliminary work and are circulated to encourage discussion. Citation of such a paper should account for its provisional character. A revised version may be available directly from the author. 
IZA Discussion Paper No. 5954

September 2011

\section{ABSTRACT \\ Women's Age at First Marriage and Marital Instability: Evidence from the 2006-2008 National Survey of Family Growth}

One of the most salient demographic trends in the U.S. landscape in recent decades has been the pronounced increase in age at first marriage. This paper examines the implications of women's delayed entry to marriage for marital stability using data from the 2006-2008 National Survey of Family Growth. The main finding is that the association between age at marriage and marital instability without holding constant the couple's characteristics at marriage is negative up to the late twenties, with the curve leveling off thereafter. Women who marry in the late twenties and thirties generally enter unconventional matches (e.g., the husband is more likely to have been married before, and to be younger than the wife by three years or more), suggestive of a "poor match" emerging as the biological clock begins to tick. However, the flattening out of the curve beyond the late twenties suggests that the stabilizing influence associated with greater maturity at older ages is strong enough to cancel out the poor match effect.

JEL Classification: J12

Keywords: divorce, marriage dissolution, marital instability, marriage

Corresponding author:

Evelyn L. Lehrer

Economics Department (M/C 144)

University of Illinois at Chicago

601 South Morgan Street

Chicago, IL 60607

USA

E-mail: elehrer@uic.edu 
Women's Age at First Marriage and Marital Instability:

Evidence from the 2006-2008 National Survey of Family Growth

The steady increase in age at first marriage has been one of the most salient demographic trends in the U.S. landscape in recent decades. The median age rose from 20 and 23 for women and men, respectively, in 1950-1960, to 26 and 28 in 2010 (U.S. Census Bureau 2010). Several factors contributed to this trend, including the development of oral contraception and the legalization of abortion, the growth in cohabitation, changes in household technology, and the decline in the male-female wage gap (Goldin \& Katz 2002; Cherlin 2004; Greenwood \& Guner 2008; Isen \& Stevenson 2011). An important issue concerns the implications that this pattern of delayed entry into first marriage may have for marital stability. The present paper examines this question, focusing on women's age at first marriage.

Becker's (1973) pioneering research on the economics of marriage found that in the optimal sorting there is positive assortative mating for traits that are complementary within the context of marriage and negative assortative mating for traits that are substitutes. Subsequent research developed the idea that when such sorting does not occur along important dimensions and the resulting gains from marriage are low, the outcome is a high probability of divorce (Becker et al. 1977). Expanding on these insights, Oppenheimer (1988) advanced the notion of a "maturity effect:" marriages contracted at an early age are at higher risk of disruption because they are more likely to be based on mistaken expectations. At young ages individuals have inadequate self knowledge and are uncertain about their own and their partners' potential trajectories. Moreover, some of their adult attributes have not yet emerged, making assortative mating by such traits impossible. The maturity effect postulates a stabilizing influence associated with later age at marriage.

Women's age at first marriage is also associated with the probability of divorce in two indirect ways. First, women who enter marriage at a later age differ from their counterparts 
who do so when they are younger in several respects, with varying implications for marital stability. For example, they tend to be more educated (a stabilizing influence); they also are more likely to wed men who have been married previously (a destabilizing influence). Second, Becker et al. (1977) suggested the possibility of a "poor match" effect emerging at older ages: the ticking of the biological clock may lead women who reach their late twenties/thirties in the single state to revise their expectations downward and settle for a partner who is far from the optimal match. If this influence is strong enough, the "total effect," i.e., the relationship between age at first marriage and marital instability without controlling for the spouses' characteristics at the time of marriage, would be U-shaped: after a certain point, age at marriage and the probability of dissolution would be positively related.

Using data from the 1960s, Becker et al. (1977) found evidence of such U-shape, and interpreted the slight positive relationship emerging after age 30 as evidence of a dominant poor match effect at these later ages. Analyses of two more recent data sets-- cycles 5 and 6 of the National Survey of Family Growth (NSFG) conducted, respectively, in 1995 and 2002-- found a different pattern: the association between age at first marriage and marital stability (without controlling for the characteristics of the couple) is strongly negative until the mid twenties, with the curve leveling off thereafter (Lehrer 2008). Additional analyses of these data found that women who delay marriage beyond the late twenties tend to make matches of poorer quality in some respects (e.g., greater heterogamy in religion, education, and age), suggestive of a poor match effect. The flattening out of the curve beyond the late twenties, however, indicates that

the maturity effect-- the higher stability associated with greater maturity at older ages-- offsets the poor match effect.

The present study examines the robustness of these findings by utilizing data from cycle 7 of the NSFG. The question addressed here is: Are the patterns uncovered for cycles 5 and 6 replicated in the more recent cycle 7 data?

\section{METHODS}

The cycle 7 NSFG file that has been released to the public includes interviews that took place between 2006 and 2008. Conducted by the National Center for Health Statistics (NCHS), the 
questionnaires were addressed to nationally representative samples of men and women ages 15-44 of all marital statuses living in the United States. This study uses the female sample ( $n=$ 7,356). As in the earlier study based on cycles 5 and 6, only non-Hispanic white women were considered -- limitations of sample size precluded analyses of separate samples for other racial/ethnic groups. This restriction led to a sample of $n=3,869$ cases. Elimination of respondents who had never been married brought the sample to $n=1,985$. After excluding observations with invalid data for the key variables, the final sample size was $n=1,971$.

The associations of age at marriage and other characteristics with marital stability were assessed using Cox proportional hazards models. Survival time was defined as the interval between the respondent's first marriage and the date of marriage dissolution, measured at the time of separation (or divorce, for cases with missing data on date of separation). First marriages that had not been dissolved were treated as censored as of the interview date; cases of widowhood were treated as censored at date of husband's death. In addition to the coefficients, standard errors and hazard ratios, we report estimated fifth-year dissolution probabilities-- the complement of the survival function evaluated at 5 years.

\section{RESULTS}

Table 1 provides descriptive statistics for the variables used in the analyses. The explanatory variable of central interest- age at first marriage- was specified as a series of dummy variables. Consistent with the rising age at first marriage in recent decades, the percentage of marriages taking place at age 27 or later climbed from $15 \%$ in cycle 5 to $23 \%$ in cycle 6; the figure rose further to $25 \%$ in cycle 7 . We grouped the other explanatory variables into three categories: (a) wife's background characteristics; (b) wife's characteristics at the time of marriage; and (c) characteristics of the husband and couple at the time of marriage.

Table 2 reports the Cox proportional hazards regressions. Panel A, which controls only for the wife's background characteristics, provides an estimate of the total effect associated with her age at first marriage. Panel B adds controls for the wife's characteristics at marriage. Panel C also includes controls for the husband's and couple's characteristics, providing an estimate of the maturity effect. 
Panel A shows that the fifth-year dissolution probability is 0.33 for women who entered first marriage before age 20 , and declines steadily to 0.09 for those who did so at age 30-32. The probability rises slightly to 0.11 for age 33 and older, but the coefficient on the dummy variable for the 33 and older category is not significantly different than that for the 30-32 category. In addition, the coefficient on the 30-32 dummy is not significantly different from that for the 27-29 dummy. Thus, mirroring the findings for cycles 5 and 6 , the curve that shows the total effect of age at marriage on divorce is steeply downward sloping up to the late twenties, leveling off thereafter.

The estimated associations between the other variables and the odds of marital dissolution are generally in accordance with earlier findings in the literature (see reviews by Weiss 1997; Lehrer 2003; Lyngstad \& Jalovaara 2010), and are described here only briefly. Marital instability is higher among respondents with a broken family background, and there is some evidence of a destabilizing effect associated with being raised with no religious affiliation. The likelihood of experiencing marital instability is markedly lower for women who enter first marriage with a college education, and substantially higher for those who do so having already had a child. Unions involving a husband who had been previously married are also more unstable, as are couples composed of partners with different race/ ethnicity. With regard to age heterogamy, the point estimates suggest that when the wife is older than the husband by 3 years or more the marriage is less stable, but the difference does not attain significance at conventional levels ( $p$-value $=0.11)$.

Approximately $36 \%$ of respondents in cycle 5 had shared living arrangements with their spouse prior to marriage, and by cycle 6 the figure had risen to 50\%. The cycle 7 estimate is $56 \%$, consistent with other evidence showing that premarital cohabitation has become the normative path towards formal marriage (Wilcox \& Marquardt 2010). Still, although selectivity into cohabitation has diminished considerably, those who do not cohabit continue to display more stable unions.

Table 3 displays selected characteristics of the respondents and their partners by the wife's age at first marriage. Women who enter marriage in their late twenties or after are more 
likely than their counterparts who do so earlier to have completed 16 years of schooling or more, by a wide margin. Cycle 7 does not contain information on the husband's education, but patterns of assortative mating by education suggest that their husbands likely had high levels of schooling also (Kalmijn 1991; Fernandez \& Rogerson 2001). In other observed dimensions of the match, however, women who married in their late twenties or later tended to form unions with characteristics normally associated with higher marital instability: they were more likely to cohabit prior to marriage, and they were also more likely to wed men who had been previously married and who were younger than them by three years or more. These patterns closely mirror those uncovered earlier, for cycles 5 and 6, and are suggestive of a "poor-match effect" emerging as the biological clock begins to tick. Cycle 5, which had richer data on husband's characteristics, showed that women who postpone marriage are also more likely to enter unions that are heterogamous in education and religion.

Yet in all cycles -- 5, 6 and 7-- the curve showing the "total effect" is downward sloping until age 27-29 and flat thereafter, i.e., there is no U-shape. Women who marry in their late twenties or after have marriages that are very solid. These results suggest the interpretation that while women who postpone marriage have a higher propensity to enter unconventional marriages involving "poor matches," they may be well matched with their partners in unobserved dimensions, such as leisure preferences or life philosophies. Furthermore, whatever difficulties these unconventional matches may pose, the greater maturity that comes with older ages may help address them.

\section{CONCLUDING REMARKS, QUALIFICATIONS, AND DIRECTIONS FOR FURTHER RESEARCH}

The results presented in this paper replicate earlier findings based on cycles 5 and 6 of the NSFG. While the discussion above emphasized the flattening out of the curve after the late twenties, the most salient aspect of the age at marriage- marital instability relationship is the steep downward sloping curve between the teens and the late twenties. The divorce rate has been declining in the U.S. since the early 1980s (Stevenson \& Wolfers 2007; Cherlin 2010; Isen 
\& Stevenson 2011) and the present findings suggest that the trend toward delayed marriage since the 1960s was likely an important contributing factor.

The simple statistics on median age at first marriage with which we opened this paper mask considerable variation by education, as does the above statement on the overall falling divorce rate in recent decades. Table 3 indicates that it is the more highly educated women who are delaying entry to first marriage, and Table 2 shows that it is these women who are going on to solid unions-- both their high education and their older age at marriage contribute to marital stability. Tables 2 and 3 also show that, at the other end of the spectrum, women with low levels of education tend to enter marriage at young ages and the unions they form are fragile. Related research has noted that more and less advantaged SES groups in the U.S. have been following divergent trajectories, not only in the patterns of age at marriage and divorce discussed here, but also in trends of female employment, out-of-wedlock childbearing, and fathers' involvement with children. The result has been a widening gap in resources available to children from these groups as the second demographic transition has unfolded (McLanahan 2004). The divergence has been caused partly by rising income inequality spurred by technological change and globalization, and partly by major socio-economic and cultural transformations including changes in women's bargaining power brought about by the contraceptive revolution (Akerlof et al. 1996; McLanahan 2004; Lemieux 2008).

Comparison of the estimated association between women's education and marital stability for cycles 5, 6 and 7 reveals noteworthy changes. The cycle 5 results showed that the marriages of women with moderate levels of education (12-15 years of schooling) were significantly more stable than those of their counterparts who were high-school dropouts. In contrast, the cycle 6 estimates showed no significant difference between the stability of unions formed by women with 12-15 years of schooling compared to those with less than 12 years, and that pattern also prevails in the cycle 7 estimates presented here. These findings are consistent with recent research showing that the "moderately educated middle" (i.e., those who do not have a four-year college degree but have completed high school) increasingly resemble high school dropouts in their patterns of marriage, divorce, and other demographic 
and economic behaviors (Wilcox and Marquardt 2010). Further studies on the seeming disappearance of "middle America" -- assessing the robustness of these findings with other data sets and methodologies -- will undoubtedly be a high priority in the research agenda in years to come.

Table 2 controls for factors found in earlier studies to be predictive of divorce - wife's background, wife's characteristics at marriage, characteristics of the husband and couple at marriage. But of course there are a host of unobserved relevant factors in each of these categories. In particular, our estimate in Panel A of the "total effect" must be qualified as subject to omitted variables biases. A recent study focusing on the adverse effect of marriage at very young ages on subsequent economic status was able to obtain a consistent estimate by using variations across states in minimum-age-at-marriage laws as an instrument (Dahl 2005). A similar approach could be used to obtain a consistent estimate of the adverse effect on marital stability, using data with information on state of residence at the time of marriage. However, the non-linearities uncovered in the present study indicate that simple extrapolation to the older ages - the late twenties and beyond--would be inappropriate.

Although differences between the partners in religious affiliation have been found to be associated with a higher probability of marriage dissolution in many studies (Lehrer \& Chiswick 1993; Kalmijn et al. 2005; Vaaler et al. 2009), our findings suggest that inter-faith marriages contracted at a late age may be as solid as their intra-faith counterparts. Similarly, the destabilizing effects typically associated with education, age, and race/ ethnicity heterogamy may not be present for couples that have delayed marriage. We were unable to test these hypotheses by modeling interactions between age at first marriage and characteristics of the match, because of the small number of cases corresponding to unions formed beyond the late twenties. Exploration of these interactions using data with larger sample sizes is a fruitful avenue for future research. 


\section{References}

Akerlof GA, Yellen JL \& and Katz MI (1996) An analysis of out-of-wedlock childbearing in the United States. Quarterly Journal of Economics 111:277-317.

Becker G. (1973) A theory of marriage. Pp. 299-344 in Schultz TW (ed.) Economics of the Family: Marriage, Children, and Human Capital. Chicago: The University of Chicago Press.

Becker G, Landes EM \& Michael RT (1977) An economic analysis of marital instability. Journal of Political Economy 85(6):1141-1187.

Cherlin AJ (2004) The deinstitutionalization of American marriage. Journal of Marriage and the Family 66 (November): 848-861.

Cherlin AJ (2010) Demographic trends in the United States: A review of research in the 2000s. Journal of Marriage and the Family 72: 403-419.

Dahl GB (2005) Early teen marriage and future poverty. National Bureau of Economic Research, Working Paper \#11328.

Fernandez R \& Rogerson R (2001) Sorting and long-run inequality. Quarterly Journal of Economics 116:1305-1341.

Goldin C \& Katz L (2002)The power of the pill: Oral contraceptives and women's career and marriage decisions. Journal of Political Economy 110(4): 730-770.

Greenwood J \& Guner N (2008) Marriage and divorce since World War II: Analyzing the role of technological progress on the formation of households. NBER Macro Annual. Cambridge: NBER.

Isen A \& Stevenson B (2011) Women's education and family behavior: Trends in marriage, divorce and fertility. Forthcoming in Demography. 
Kalmijn M(1991) Shifting boundaries: Trends in religious and educational homogamy. American Sociological Review 56: 768-780.

Kalmijn M, de Graaf PM \& Janssen JPG (2005) Intermarriage and the risk of divorce in the Netherlands: The effects of differences in religion and nationality. Population Studies 59(1): 71-85.

Lehrer EL (2003) The economics of divorce. Pp. 55-74 in Grossbard-Shechtman S (ed.) Marriage and the Economy: Theory and Evidence from Industrialized Societies. Cambridge: Cambridge University Press.

Lehrer EL (2008) Age at marriage and marital instability: Revisiting the Becker-LandesMichael hypothesis. Journal of Population Economics 21(2):463-484.

Lehrer EL and Chiswick CU (1993) Religion as a determinant of marital instability. Demography 30(3): 385-404.

Lemieux T (2008) The changing nature of wage inequality. Journal of Population Economics 21:21-48.

Lyngstad TH \& Jalovaara M (2010) A review of the antecedents of union dissolution. Demographic Research 23, article 10:257-292.

McLanahan S (2004) Diverging destinies: How children fare under the second demographic transition. Demography 41(4): 607-628.

Oppenheimer VK (1988) A theory of marriage timing. American Journal of Sociology 94(3):563-591.

Stevenson B \& Wolfers J (2007) Marriage and divorce: Changes and their driving forces. Journal of Economic Perspectives 21(2): 27-52.

U.S. Census Bureau (2010) www.census.gov/population/socdemo/hh-fam/ms2.xls 
Vaaler ML, Ellison CG \& Powers DA (2009) Religious influences on the risk of marital dissolution. Journal of Marriage and the Family 71(4): 917-934.

Weiss $Y(1997)$ The formation and dissolution of families: Why marry? Who marries whom? And what happens upon divorce? Pp 81-123 in Rosenzweig MR \& Stark O (eds.) Handbook of Population and Family Economics, V 1A. Amsterdam: Elsevier.

Wilcox, WB \& Marquardt E (eds.) (2010) The State of our Unions, 2010. Charlottesville, Virginia: The National Marriage Project and the Institute for American Values. 
Table 1. Descriptive Statistics

\begin{tabular}{|c|c|c|}
\hline Variable & Definition & Mean \\
\hline Wife's Age at Marriage & $\begin{array}{l}=1 \text { if respondent's }(\mathrm{R}) \text { age at marriage was in category } \\
\text { indicated }\end{array}$ & \\
\hline Less than 20 & & 0.16 \\
\hline$(20-26)$ & & $(0.60)$ \\
\hline $27-29$ & & 0.13 \\
\hline $30-32$ & & 0.07 \\
\hline 33 or older & & 0.05 \\
\hline \multicolumn{3}{|l|}{$\begin{array}{l}\text { Wife's Background } \\
\text { Characteristics }\end{array}$} \\
\hline Family of origin not intact & $=1$ if R's family of origin was not intact & 0.32 \\
\hline Unaffiliated & $=1$ if $\mathrm{R}$ was raised with no religious affiliation & 0.09 \\
\hline \multicolumn{3}{|l|}{$\begin{array}{l}\text { Wife's Characteristics at } \\
\text { Marriage }\end{array}$} \\
\hline Education & $\begin{array}{l}=1 \text { if at date of first marriage, R's education was in } \\
\text { category indicated }\end{array}$ & \\
\hline Less than 12 years & & 0.15 \\
\hline$(12-15$ years $)$ & & $(0.52)$ \\
\hline 16 years or more & & 0.33 \\
\hline Child from previous union & $\begin{array}{l}=1 \text { if } \mathrm{R} \text { had had a live birth prior to the date of first } \\
\text { marriage }\end{array}$ & 0.18 \\
\hline
\end{tabular}


Table 1 (continued)

\begin{tabular}{llc}
\hline Variable & Definition & Mean \\
\hline $\begin{array}{l}\text { Characteristics of } \\
\text { husband and couple } \\
\text { at marriage }\end{array}$ & & 0.15 \\
$\begin{array}{l}\text { Husband married before } \\
\text { No premarital cohabitation }\end{array}$ & $=1$ if R did not cohabit with husband prior to marriage & 0.44 \\
Different race/ ethnicity & $=1$ if husband is non-white and/or Hispanic & 0.08 \\
Age composition & $=1$ if difference between husband's and wife's age is & 0.18 \\
$\begin{array}{l}6 \text { years or more } \\
-3 \text { years or less } \\
\text { (more than -3; less than 6) }\end{array}$ & as indicated & 0.04 \\
$\mathrm{~N}$ & & $(0.78)$ \\
\hline
\end{tabular}


Table 2. Cox Proportional Hazards Models of Divorce (standard errors in parentheses)

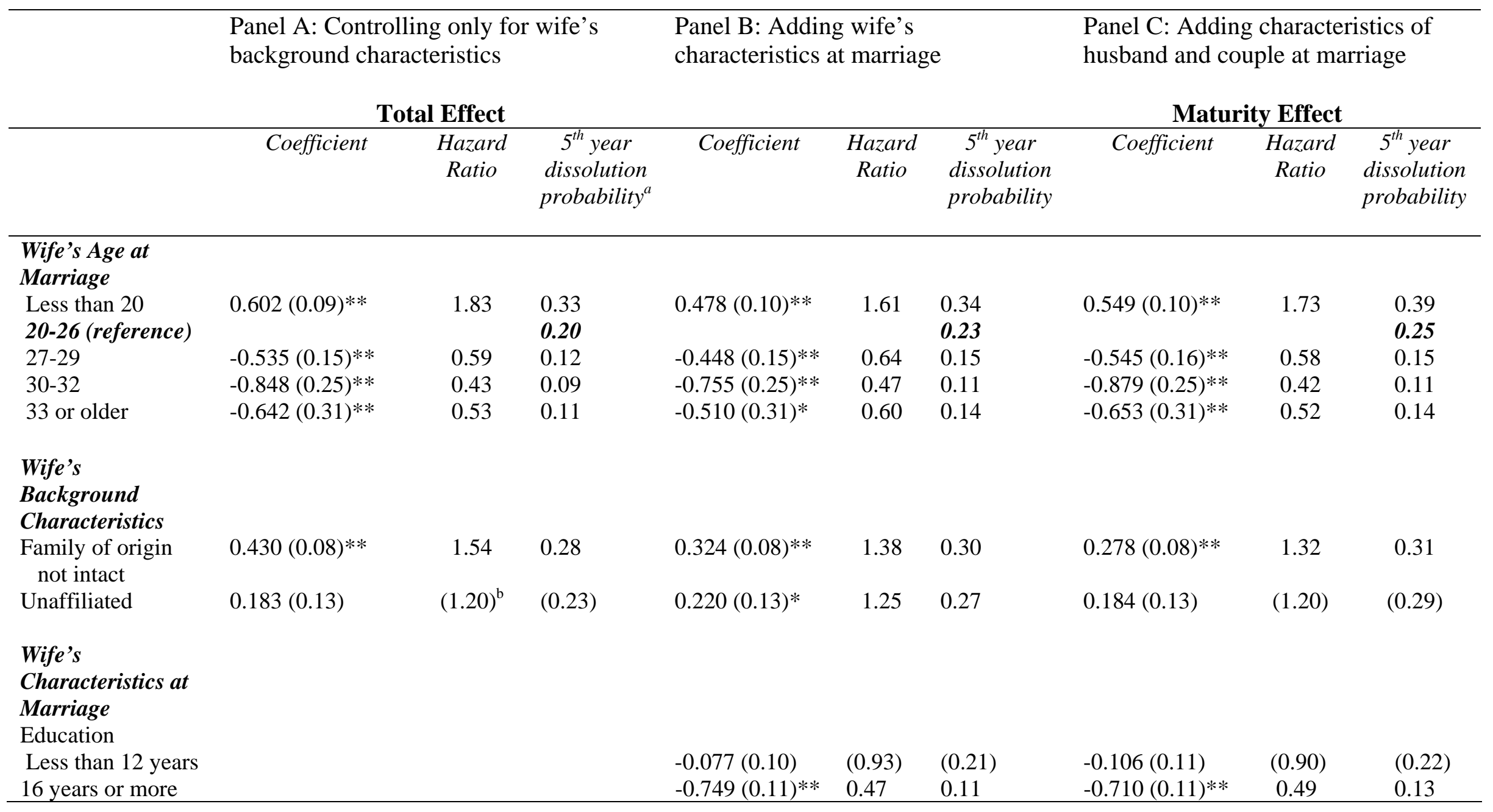


Table 2 (continued)

\begin{tabular}{|c|c|c|c|c|c|c|c|c|c|}
\hline & \multicolumn{3}{|c|}{ Panel A } & \multicolumn{3}{|c|}{ Panel B } & \multicolumn{3}{|c|}{ Panel C } \\
\hline & Coefficient & $\begin{array}{c}\text { Hazard } \\
\text { Ratio }\end{array}$ & $\begin{array}{c}5^{\text {th }} \text { year } \\
\text { dissolution } \\
\text { probability }\end{array}$ & Coefficient & $\begin{array}{c}\text { Hazard } \\
\text { Ratio }\end{array}$ & $\begin{array}{c}5^{\text {th }} \text { year } \\
\text { dissolution } \\
\text { probability }\end{array}$ & Coefficient & $\begin{array}{c}\text { Hazard } \\
\text { Ratio }\end{array}$ & $\begin{array}{c}5^{\text {th }} \text { year } \\
\text { dissolution } \\
\text { probability }\end{array}$ \\
\hline Child from previous union & & & & $0.372(0.10)^{* *}$ & 1.45 & 0.31 & $0.253(0.10)^{* *}$ & 1.29 & 0.30 \\
\hline \multicolumn{10}{|l|}{$\begin{array}{l}\text { Characteristics of Husband } \\
\text { and Couple at Marriage }\end{array}$} \\
\hline Husband married before & & & & & & & $0.192(0.12)^{*}$ & 1.21 & 0.29 \\
\hline No premarital cohabitation & & & & & & & $-0.253(0.09)^{* *}$ & 0.78 & 0.20 \\
\hline Different race/ethnicity & & & & & & & $0.352(0.13)^{* *}$ & 1.42 & 0.33 \\
\hline \multicolumn{10}{|l|}{ Age difference } \\
\hline 6 years or more & & & & & & & $-0.099(0.11)$ & $(0.91)$ & $(0.22)$ \\
\hline-3 years or less & & & & & & & $0.382(0.24)$ & $(1.47)$ & $(0.34)$ \\
\hline
\end{tabular}

$$
\mathrm{n}=1,971
$$

a The "reference woman" is a respondent who entered her first marriage at age 20-26 and whose other characteristics are also typical, i.e., all explanatory variables are set at the modal category. The other probabilities shown in this table correspond to respondents who differ from the reference woman in only one trait, as noted in the stub.

${ }^{\mathrm{b}}$ Hazard ratios and probabilities are shown in parentheses when the corresponding coefficient is not significant at the 0.10 level.

$* * \mathrm{p}<0.05 ; * \mathrm{p}<0.10$ 
Table 3. Selected Characteristics by Respondent's Age at Marriage ${ }^{\text {a }}$

\begin{tabular}{|c|c|c|c|c|c|}
\hline & \multicolumn{5}{|c|}{ Age at Marriage } \\
\hline & $<20$ & $20-26$ & $27-29$ & 30 or older & $\begin{array}{c}\chi^{2} \text { test } \\
\text { (p-value) }\end{array}$ \\
\hline \multicolumn{6}{|l|}{ Wife's Characteristics at Marriage } \\
\hline Less than 12 years & 43.65 & 9.35 & 11.55 & 8.85 & $<.01$ \\
\hline 16 years or more & 3.58 & 33.02 & 51.39 & 50.44 & \\
\hline Child from previous union & 15.96 & 17.44 & 17.13 & 23.01 & 0.17 \\
\hline \multicolumn{6}{|c|}{$\begin{array}{l}\text { Characteristics of Husband and Couple } \\
\text { at Marriage }\end{array}$} \\
\hline Husband married before & 9.45 & 11.71 & 21.12 & 29.65 & $<.01$ \\
\hline Premarital cohabitation & 42.02 & 53.16 & 72.51 & 75.66 & $<.01$ \\
\hline Age difference: - 3 years or less & 0.00 & 1.35 & 7.17 & 17.26 & $<.01$ \\
\hline Race/ethnicity difference & 10.42 & 7.50 & 6.77 & 6.64 & 0.27 \\
\hline
\end{tabular}

$\mathrm{n}=1,971$

${ }^{\text {a }}$ Figures reported are percentage of cases with dummy variable equal to 1. 